American J. of Engineering and Applied Sciences 3 (2): 293-299, 2010

ISSN 1941-7020

(C) 2010 Science Publications

\title{
Reference Solar Radiation Year and Some Climatology Aspects of East Coast of West Malaysia
}

\author{
${ }^{1}$ Abdul Majeed Muzathik, ${ }^{1}$ Wan Mohd Norsani Bin Wan Nik, \\ ${ }^{1}$ Khalid Bin Samo and ${ }^{2}$ Mohd Zamri Ibrahim \\ ${ }^{1}$ Department of Maritime Technology, Faculty of Maritime Studies and Marine Science, \\ ${ }^{2}$ Department of Engineering Science, Faculty of Science and Technology, \\ University Malaysia Terengganu, 21030 Kuala Terengganu, Malaysia
}

\begin{abstract}
Problem statement: This study examined in detail some aspects of radiation climatology for Terengganu state in Malaysia. The geographical co-ordinates of the site are $5^{\circ} 10^{\prime} \mathrm{N}$ latitude $103^{\circ} 06^{\prime} \mathrm{E}$ longitude and $5.2 \mathrm{~m}$ altitude. Approach: The data used in the present study were taken from a recording data station installed at site by the Malaysian Meteorology Department (2004). In addition to this, wind speed, solar radiation and air temperature data taken from University Malaysia Terengganu Renewable Energy Station were also analyzed. The averaged solar radiation year for Terengganu is generated from mid-term daily global solar radiation data. The averaged data of the daily global solar radiation for the locations considered are presented in a tabular form for a complete year. Results: The highest daily and monthly mean global solar irradiation values were 7560 and $6566 \mathrm{Wh} \mathrm{m}^{-2} \mathrm{day}^{-1}$, respectively. The highest hourly average solar irradiance intensity was $1139 \mathrm{~W}$ $\mathrm{m}^{-2}$ during this study period. Yearly average daily solar energy was $18.92 \mathrm{MJ} \mathrm{m}^{-2} \mathrm{day}^{-1}$. Besides the global solar radiation, the clearness indexes, wind speed and air temperature variation are discussed. Conclusion/Recommendations: The results in this study will fill the gap that complete and detailed reference solar radiation and climatologically data, which are not available for Terengganu state of Malaysia and will be useful to the designers of solar energy conversion and utilization devices.
\end{abstract}

Key words: Air temperature variation, averaged solar radiation year, clearness index, daily mean solar radiation, monthly mean wind speed

\section{INTRODUCTION}

Energy is essential to economic and social development and improved quality of life of human being. Solar energy is being seriously considered for satisfying a significant part of energy demand in Malaysia, as is in the world. Furthermore, with the increase in energy demand, the issue of energy shortage becomes increasingly serious. Since there is more and more concern on energy conservation and environmental protection, interest has been increasingly focused on the use of solar energy. Solar energy, as a clean energy source and one kind of renewable energy, is abundant in Malaysia.

An accurate knowledge of the solar radiation data at a particular geographical location is of vital importance for the development of solar energy devices and for estimates of their performances (Duffie and Beckman, 2006). In this respect, the importance of solar radiation data for design and efficient operation of solar energy systems has been acknowledged. In particular, the clearness index of the area, in addition to other meteorological information such as wind speed and air temperature for a specific period, is extremely important to assess the feasibility of a solar-driven project.

Further, in recent years, few individual studies have been carried out on this subject for different locations of Malaysia (Chuah and Lee, 1981; 1982; Hu and Lim, 1983; Kamaruzzaman and Othman, 1992; Li and Lam, 2000; Wong and Chow, 2001; Abdul Karim and Razali, 2002; Azhari et al., 2008; Zaharim et al., 2009). Few models have been tested and few studies based on these models have been performed to estimate solar energy potential. The solar radiation estimates for Peninsula Malaysia were published by Chuah and Lee $(1981$; 1982) for three major towns, namely Kuala Lumpur, Penang and Kota Bharu, who used the

Corresponding Author: Abdul Majeed Muzathik, Department of Maritime Technology,

Faculty of Maritime Studies and Marine Science, University Malaysia Terengganu,

21030 Kuala Terengganu, Malaysia 
Angstrom type regression equation to clear day radiation at the locations. Monthly average solar radiation on the horizontal surface in Kuching, Kota Kinabalu, Kota Bharu, Senai, Bayan Lepas, Kuala Lumpur, Petaling Jaya and Bandar Baru Bangi were studied by Kamaruzzaman and Othman (1992), who used the simplified Angstrom model. Zaharim et al. (2009) used Box-Jenkins method to predict the global solar radiation at Bangi. Two statistical methods were used to forecast the monthly average daily solar radiation based on the meteorological factors such as sunshine hours, relative humidity, total rainfall and wind speed in Sultan Abdul Aziz Shah Subang Airport. Azhari et al. (2008) used satellite images to predict the solar energy as an alternative method. Although solar radiation data have been reported for few regions in Malaysia, reliable and yearlong global radiation data is still needed for Terengganu state. This study therefore addresses this need.

\section{MATERIALS AND METHODS}

Data observations and procedure: In this study, the global solar radiation data were taken from the Malaysian Meteorological Department (2004-2008) through e mail for the study location. There were missing and invalid measurements in the data and they were marked and coded as 11111 in the files. The missing and invalid measurements, accounting for approximately $0.50 \%$ of the whole database, were replaced with the values of preceding or subsequent hours of the day by interpolation. The geographical coordinates of the site are $5^{\circ} 10^{\prime} \mathrm{N}$ latitude $103^{\circ} 06^{\prime} \mathrm{E}$ longitude and $5.2 \mathrm{~m}$ altitude. In addition to MMD data, solar radiation, wind speed and air temperature data collected from University Malaysia Terengganu Renewable Energy Station, which is nearly $2 \mathrm{~km}$ northwest to the Kuala Terengganu MMD station, were also used. The meteorological data were collected every 10 min using a computer at this station. The surface air temperature and the global solar radiation measurement instruments were set at $6 \mathrm{~m}$ above the ground level. A LI-COR, LI-200SZ pyranometer was used to measure the global solar radiation. The wind speed measurement instruments were set at $18 \mathrm{~m}$ above the ground level. The sensors were checked and calibrated to ensure the quality of the data collected. From the raw data stored, the mean, maximum and minimum hourly values were calculated. From the hourly data set, daily and monthly statistics were made for the solar radiation, wind speed and temperature data. In this study, average solar radiation data for Terengganu were generated by using the daily global solar radiation recorded during the period 2004-2008.

\section{RESULTS AND DISCUSSION}

Solar radiation: The amount of solar radiation received by the earth's surface varies from one place to another owing to the attenuating properties of the atmosphere and the diverse geographical characteristics of the earth's surface. Generally, from the collected data it is clear that the daily average and maximum global radiations as well as temperatures are higher from February to September and lower from October to January. Figure 1 describes the daily average and daily maximum global solar irradiance for the whole year 2004. The graphs show that the daily maximum global irradiance of $1139 \mathrm{~W} \mathrm{~m}^{-2}$ was recorded on April 5, 2004. The highest daily solar irradiation of $8089.30 \mathrm{~W} \mathrm{~m}^{-2}$ day $^{-1}$ was recorded on March 5, 2007. Daily mean solar irradiance values were high during the periods of February to May and July to October. Average daily energy input for the whole year was $18.92 \mathrm{MJ} \mathrm{m}^{-2} \mathrm{day}^{-1}$, which agrees with the global solar map (SOLAR4POWER, 2009). Figure 1 also shows downward excursions in northeast monsoon, especially in November, December and January. These excursions might be due to rain and higher air mass.

Daily averages for each month and peak daily global solar radiations for a complete year are shown in Fig. 2. The month of April had the highest monthly average daily irradiation of $6566 \mathrm{~W} \mathrm{~m}^{-2}$ day $^{-1}$ and the highest daily peak in solar irradiation of $7560 \mathrm{~W} \mathrm{~m}^{-2}$ day $^{-1}$.

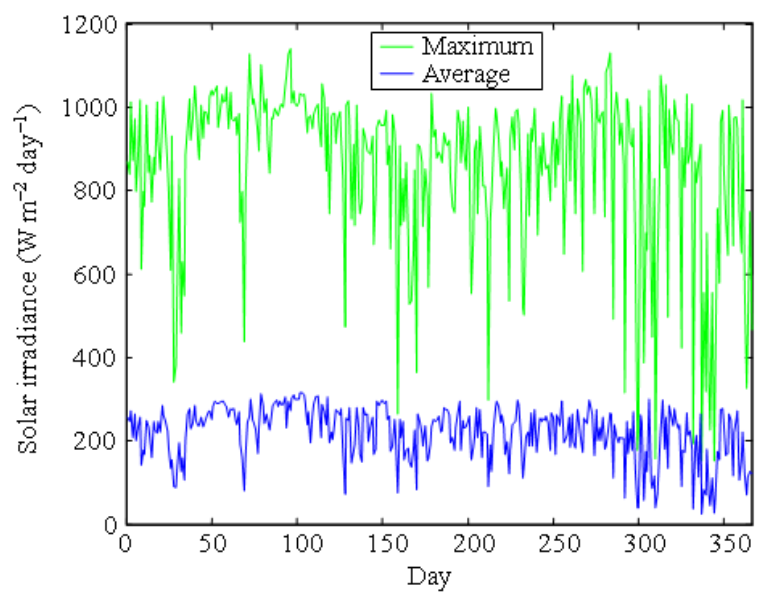

Fig. 1: Daily average and daily peak of global solar irradiance throughout the year 2004 at the research site 
Am. J. Engg. \& Applied Sci., 3 (2): 293-299, 2010

Table 1: Monthly mean daily values of global solar irradiation for Kuala Terengganu (2004) and other cities

\begin{tabular}{|c|c|c|c|c|c|c|c|c|c|}
\hline \multirow[b]{2}{*}{ Months } & \multicolumn{9}{|c|}{ Global irradiation, $\mathrm{H}\left(\mathrm{MJ} \mathrm{m}^{-2}\right.$ day $\left.^{-1}\right)$} \\
\hline & $\begin{array}{l}\text { Kuala } \\
\text { Terengganu }\end{array}$ & Kuching & $\begin{array}{l}\text { Kota } \\
\text { Kinabalu }\end{array}$ & $\begin{array}{l}\text { Kota } \\
\text { Bharu }\end{array}$ & Senai & $\begin{array}{l}\text { Bayan } \\
\text { Lepas }\end{array}$ & $\begin{array}{l}\text { Kuala } \\
\text { Lumpur }\end{array}$ & $\begin{array}{l}\text { Petaling } \\
\text { Jaya }\end{array}$ & $\begin{array}{l}\text { Bandar } \\
\text { Baru Bangi }\end{array}$ \\
\hline $\begin{array}{l}\text { January } \\
\end{array}$ & 17.91 & 12.02 & 17.71 & 16.26 & 15.08 & 19.10 & 15.44 & 15.28 & 13.17 \\
\hline February & 21.60 & 13.35 & 19.36 & 17.72 & 20.05 & 19.56 & 16.89 & 16.99 & 15.99 \\
\hline March & 21.40 & 15.39 & 20.97 & 19.72 & 16.80 & 20.06 & 17.26 & 15.71 & 14.85 \\
\hline April & 23.64 & 13.07 & 21.64 & 19.74 & 17.10 & 18.98 & 17.71 & 16.68 & 16.07 \\
\hline May & 20.34 & 13.42 & 20.16 & 18.23 & 15.79 & 17.51 & 16.13 & 15.83 & 15.84 \\
\hline June & 17.42 & 16.28 & 19.11 & 17.10 & 16.06 & 17.34 & 15.91 & 15.96 & 15.48 \\
\hline July & 19.43 & 16.57 & 19.41 & 17.17 & 14.92 & 17.27 & 15.87 & 15.88 & 16.76 \\
\hline August & 19.15 & 15.14 & 19.44 & 17.42 & 15.16 & 16.79 & 15.90 & 15.99 & 14.49 \\
\hline September & 20.20 & 15.79 & 18.20 & 18.12 & 15.63 & 16.66 & 16.03 & 16.08 & 14.38 \\
\hline October & 16.40 & 15.23 & 19.21 & 17.09 & 15.43 & 16.29 & 15.82 & 16.23 & 14.19 \\
\hline November & 16.24 & 14.92 & 18.08 & 13.28 & 15.30 & 17.03 & 14.36 & 14.67 & 12.28 \\
\hline December & 13.38 & 12.56 & 18.00 & 12.15 & 15.90 & 17.59 & 14.53 & 14.54 & 12.66 \\
\hline Annual average & 18.92 & 14.48 & 19.27 & 17.00 & 16.10 & 17.85 & 15.99 & 15.82 & 14.68 \\
\hline
\end{tabular}

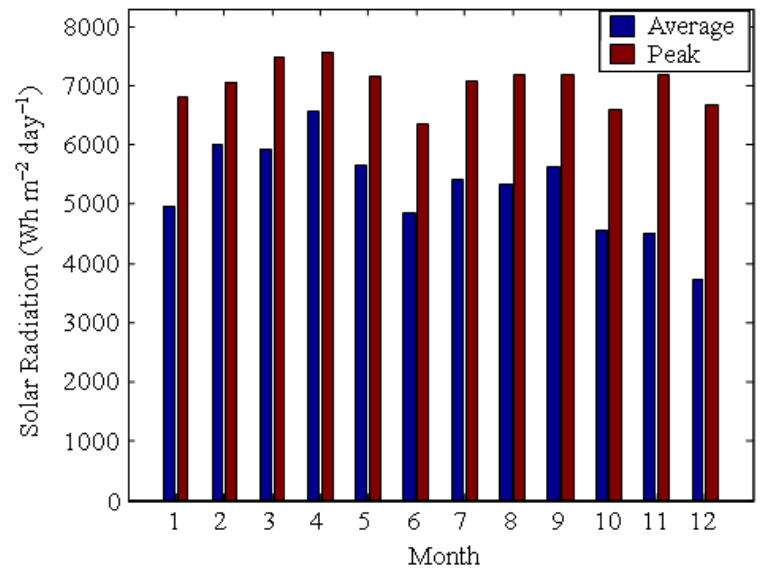

Fig. 2: Monthly average and monthly peak daily total solar irradiation at the research site

December had the lowest monthly average daily solar irradiation of $3715 \mathrm{~W} \mathrm{~m}^{-2}$ day $^{-1}$. The average yearly cumulative irradiation for Terengganu is $6905.8 \mathrm{MJ} \mathrm{m}^{-2}$ year $^{-1}$. In an average year, the dry period (February to May and September) contributes about $47.19 \%$ of the annual total. The worst month (December) contributes least, being responsible for only about $5.89 \%$.

In Table 1, the monthly mean daily values of global solar irradiation of Kuala Terengganu and other cities (Kuching, Kota Kinabalu, Kota Baru, Senai, Bayan Lepas, Kuala Lumpur, Petaling Jaya and Bandar Baru Bangi) of Malaysia (Kamaruzzaman and Othman, 1992) are compared. It is clear that the monthly average global irradiation over the course of the year 2004 is higher for Kuala Terengganu, though in October, Kota Bharu and few months Kota Kinabalu cities has higher monthly mean daily global solar irradiation values.
Generation of averaged solar radiation year: The real recorded data from past solar observations (20042008) are selected for generation of representative solar data. A representative database for the one-year duration is known as test reference year or typical meteorological year. Finkelstein-Schafer (FS) statistics are the common methodology for generating typical weather data. Many attempts have been made to produce such weather databases for different locations around the world (El-Sebaii and Trabea, 2003; Gazela and Mathioulakis, 2001; Argiriou et al., 1999; Petrakis et al., 1998; Marion and Urban, 1995; Fagbenle, 1995; Said and Kadry, 1994; Shaltout and Tadros, 1994). However in this study the averaged solar radiation year was developed using available solar data.

By using all the months' data in the database, the averaged reference year for daily global solar radiation data was developed for Terengganu state of Malaysia. Table 2 gives the averaged reference year for monthly mean global solar radiation for the location considered in this study. As can be seen from the Table 2, the minimum and maximum values of monthly mean of daily global solar irradiation on a horizontal surface are $12.95 \mathrm{MJ} \mathrm{m}^{-2} \mathrm{day}^{-1}$ in December and 23.63 $\mathrm{MJ} \mathrm{m}^{-2}$ day $^{-1}$ in April, respectively, with an annual average value of $19.15 \mathrm{MJ} \mathrm{m}^{-2} \mathrm{day}^{-1}$. The highest daily average maximum and minimum solar irradiation were 27.02 and $6.46 \mathrm{MJ} \mathrm{m}^{-2}$ day $^{-1}$ on 11 April and 24 December, respectively.

Further, Table 2 indicates that the number of days per year with irradiation below $10 \mathrm{MJ} \mathrm{m}^{-2}$ day $^{-1}$ (low level radiation days) is only 10 days and there would be 165 days during a year on which the irradiation is above $20 \mathrm{MJ} \mathrm{m}^{-2} \mathrm{day}^{-1}$ (high level radiation days). The number of low and high level radiation days were examined, a frequency distribution was established 
Am. J. Engg. \& Applied Sci., 3 (2): 293-299, 2010

showing a picture of how many times these days come single, in pairs or three or more days in a row. Out of 10 low level radiation days per annum, 5 are single day, one in successive days and once in three successive days. The high level radiation days are distributed as follows: single day, 25 times; 2 days, 13 times; 3 days, 6 times; 4 days, 3 times; 5 days, once; 6 and 7 days, twice and 10,13, 14 and 16 days, once. These are average values and from year to year there is a considerable variation to this pattern. It should be pointed out that these values are valuable for the utilization of solar energy.

Wind speed: Daily average and daily maximum surface wind speeds in Kuala Terengganu throughout the year 2006 were recorded as shown in Fig. 3. Plots of the monthly average of the mean and maximum wind speeds are shown in Fig. 4. The data show a range of monthly average wind speed variations of 2.1-4.7 $\mathrm{m} \mathrm{sec}^{-1}$. Monthly mean of the maximum wind speed were higher in the months of December to February.
Air temperature: Figure 5 shows the maximum, minimum and average air temperature for one complete year 2008 for Kuala Terengganu. The graph shows that during the northeast monsoon the air temperature was lower than $30.0^{\circ} \mathrm{C}$ when the solar radiation was lower than $5000 \mathrm{~W} \mathrm{~m}^{-2}$ day $^{-1}$.

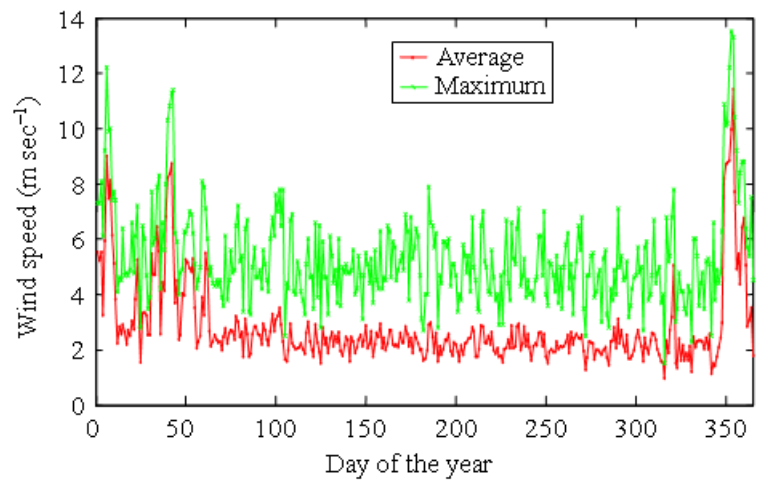

Fig. 3: Daily averages and maximum wind speed throughout the year

Table 2: Daily global solar irradiation values $\left(\mathrm{MJ} \mathrm{m}^{-2} \mathrm{day}^{-1}\right)$ obtained from averaged reference year data for Terengganu

\begin{tabular}{|c|c|c|c|c|c|c|c|c|c|c|c|c|}
\hline Day & January & February & March & April & May & June & July & August & September & October & November & December \\
\hline 1 & 13.56 & 18.71 & 21.85 & 24.66 & 21.78 & 17.63 & 18.35 & 16.79 & 20.66 & 24.18 & 23.45 & 20.36 \\
\hline 2 & 14.11 & 17.41 & 23.79 & 19.28 & 23.75 & 17.05 & 18.70 & 21.11 & 18.59 & 18.70 & 11.82 & 12.07 \\
\hline 3 & 18.36 & 17.08 & 23.87 & 22.29 & 19.40 & 13.72 & 17.98 & 20.10 & 20.14 & 19.73 & 14.45 & 18.79 \\
\hline 4 & 18.01 & 22.38 & 23.03 & 23.70 & 21.81 & 19.95 & 19.95 & 24.06 & 22.39 & 18.30 & 13.32 & 13.80 \\
\hline 5 & 17.75 & 22.84 & 21.53 & 24.38 & 19.58 & 21.19 & 19.03 & 23.51 & 14.50 & 20.46 & 16.18 & 18.95 \\
\hline 6 & 8.03 & 23.16 & 23.55 & 24.00 & 20.08 & 20.07 & 22.23 & 20.61 & 20.24 & 15.48 & 16.84 & 7.90 \\
\hline 7 & 12.06 & 22.63 & 23.21 & 26.50 & 15.96 & 17.05 & 17.78 & 21.52 & 14.96 & 16.58 & 16.91 & 7.69 \\
\hline 8 & 14.62 & 13.09 & 19.24 & 25.20 & 18.72 & 16.78 & 19.82 & 19.71 & 22.04 & 18.02 & 21.65 & 7.61 \\
\hline 9 & 13.03 & 16.86 & 20.51 & 26.54 & 18.46 & 17.08 & 18.78 & 17.03 & 20.87 & 19.75 & 18.95 & 10.41 \\
\hline 10 & 14.92 & 15.18 & 22.05 & 25.83 & 21.40 & 21.71 & 17.84 & 17.69 & 25.72 & 18.05 & 19.11 & 11.18 \\
\hline 11 & 17.28 & 20.02 & 25.32 & 27.02 & 19.86 & 16.83 & 20.86 & 17.65 & 18.17 & 17.58 & 13.48 & 7.53 \\
\hline 12 & 21.11 & 16.99 & 25.04 & 26.41 & 18.46 & 18.31 & 21.86 & 17.44 & 18.41 & 17.20 & 13.03 & 13.05 \\
\hline 13 & 21.28 & 20.21 & 18.44 & 26.27 & 20.81 & 19.36 & 23.21 & 17.19 & 19.93 & 19.14 & 18.99 & 17.54 \\
\hline 14 & 21.67 & 22.26 & 23.95 & 23.26 & 21.59 & 18.47 & 19.48 & 17.85 & 21.05 & 20.46 & 23.01 & 18.09 \\
\hline 15 & 18.84 & 24.35 & 25.29 & 23.34 & 17.59 & 18.19 & 15.63 & 21.39 & 21.63 & 19.19 & 18.52 & 14.14 \\
\hline 16 & 17.88 & 22.49 & 23.90 & 19.76 & 15.75 & 18.26 & 17.64 & 24.21 & 20.38 & 15.84 & 22.01 & 11.47 \\
\hline 17 & 18.49 & 25.58 & 22.16 & 20.27 & 13.98 & 19.45 & 19.32 & 22.52 & 17.25 & 17.00 & 17.26 & 10.63 \\
\hline 18 & 20.86 & 24.74 & 22.84 & 24.17 & 20.87 & 16.94 & 22.30 & 20.55 & 17.41 & 11.63 & 12.03 & 11.33 \\
\hline 19 & 23.03 & 22.94 & 24.16 & 20.87 & 20.57 & 20.42 & 22.34 & 18.25 & 20.40 & 14.24 & 15.54 & 17.34 \\
\hline 20 & 18.84 & 22.82 & 23.06 & 24.77 & 17.22 & 19.34 & 17.97 & 19.94 & 22.46 & 18.99 & 15.00 & 12.66 \\
\hline 21 & 21.18 & 21.23 & 21.52 & 25.65 & 15.93 & 15.26 & 17.13 & 20.77 & 20.80 & 17.83 & 12.83 & 11.21 \\
\hline 22 & 23.58 & 25.04 & 21.96 & 23.28 & 22.54 & 19.13 & 18.85 & 19.98 & 17.24 & 19.46 & 13.95 & 11.22 \\
\hline 23 & 22.89 & 24.92 & 21.32 & 22.31 & 18.31 & 19.91 & 19.50 & 21.22 & 21.23 & 16.58 & 14.98 & 16.11 \\
\hline 24 & 23.05 & 25.11 & 14.90 & 23.80 & 16.33 & 18.03 & 20.70 & 20.15 & 23.18 & 14.64 & 20.34 & 6.46 \\
\hline 25 & 20.57 & 24.81 & 19.85 & 23.72 & 16.22 & 17.13 & 17.72 & 19.62 & 20.26 & 8.82 & 15.61 & 10.92 \\
\hline 26 & 20.70 & 22.93 & 20.80 & 22.05 & 19.24 & 15.53 & 17.30 & 24.72 & 18.75 & 7.79 & 19.88 & 17.62 \\
\hline 27 & 20.63 & 26.27 & 22.17 & 24.03 & 24.15 & 15.75 & 20.31 & 20.14 & 23.11 & 20.98 & 7.92 & 15.78 \\
\hline 28 & 19.22 & 22.90 & 23.25 & 22.59 & 23.46 & 21.37 & 21.11 & 17.88 & 23.41 & 22.60 & 15.54 & 11.79 \\
\hline 29 & 18.74 & & 24.62 & 22.03 & 21.93 & 19.33 & 19.72 & 18.48 & 19.59 & 12.03 & 11.43 & 17.31 \\
\hline 30 & 20.09 & & 23.20 & 20.81 & 20.48 & 20.93 & 15.35 & 20.28 & 19.39 & 16.94 & 10.66 & 12.09 \\
\hline 31 & 19.31 & & 24.72 & & 21.46 & & 16.52 & 21.01 & & 14.59 & & 8.53 \\
\hline $\begin{array}{l}\text { Monthly } \\
\text { average }\end{array}$ & 18.51 & 21.61 & 22.42 & 23.63 & 19.60 & 18.34 & 19.20 & 20.11 & 20.14 & 17.19 & 16.16 & 12.95 \\
\hline
\end{tabular}




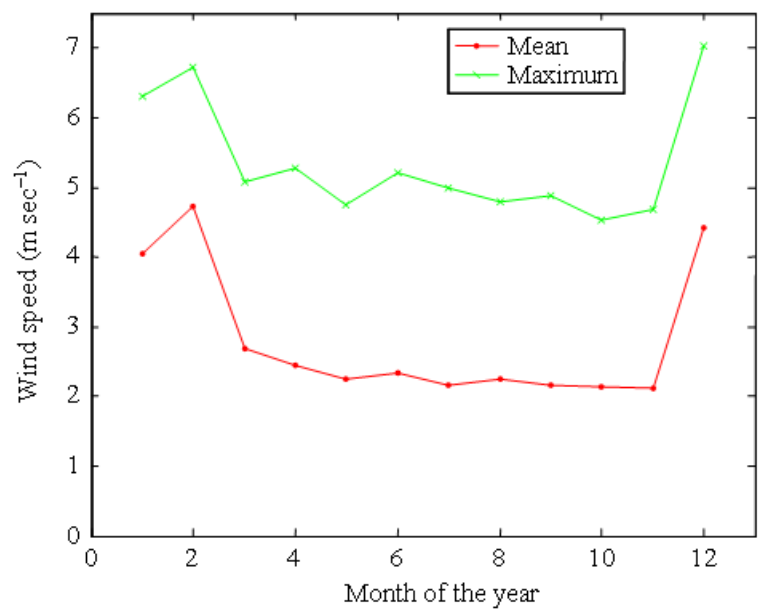

Fig. 4: Monthly average of the maximum and mean wind velocity in Kuala Terengganu

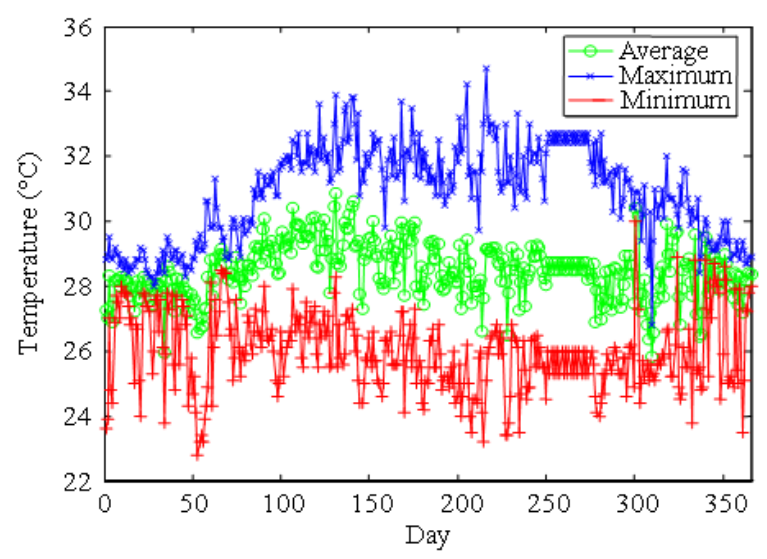

Fig. 5: Daily average, minimum and maximum temperatures throughout the year 2008, Kuala Terengganu

The highest daily maximum and monthly average temperatures were 34.5 and $29.4^{\circ} \mathrm{C}$ on 31 August and April, 2008, respectively. The minimum daily average temperature recorded was $22.8^{\circ} \mathrm{C}$ on February 22, 2008.

Figure 6 shows the monthly maximum, minimum and average air temperature for Kuala Terengganu. It is observed that maximum, minimum and average air temperature variation is very low in general during a complete year.

Clearness index: Figure 7 shows the daily variations of the clearness index for Kuala Terengganu throughout the year. It is observed that clearness index is relatively low from November through January and then it increases to a maximum (0.76) in April.

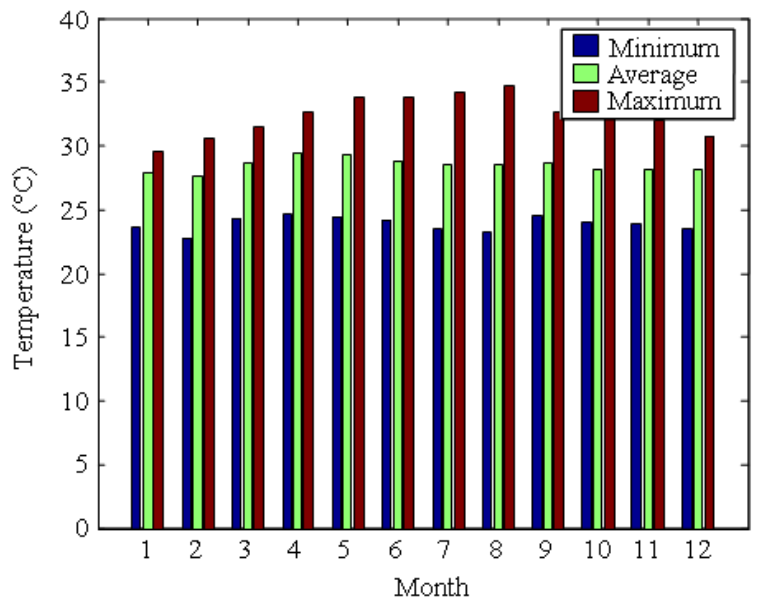

Fig. 6: Monthly average daily mean, minimum and maximum temperatures at the research site

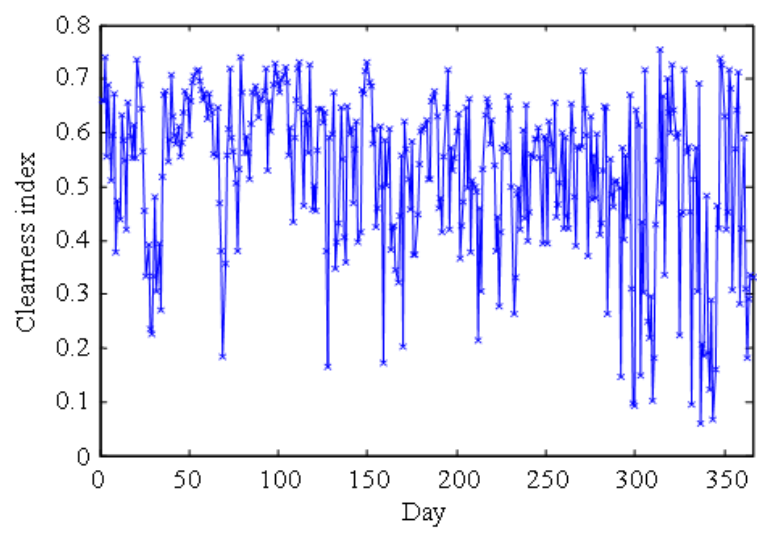

Fig. 7: Daily average clearness index variation throughout the year at the research site

There is a slight drop in the level of clearness index in June/July, with a distinct maximum in April. The variation in clearness index is attributed to the level of humidity and position of the sun relative to the site. It is rainy season from November through January, with generally high levels of moisture in the air from December through February (which reduces atmospheric transparency). The air is dry in April and May, which results in the observed peak. In general the clearness index varies between 0.06 and 0.76 during one complete year. During the northeast monsoon, the clearness indexes are very low; for other periods almost clear sky condition exists.

The variation of monthly average clearness index is shown in Fig. 8. It is seen that clearness index is maximum (0.64) during the dry hot season and lowest $(0.42)$ during the rainy season. The average clearness 
Am. J. Engg. \& Applied Sci., 3 (2): 293-299, 2010

Table 3: Monthly and annually average clearness index of Kuala Terengganu and other cities

\begin{tabular}{|c|c|c|c|c|c|c|c|c|c|}
\hline \multirow[b]{2}{*}{ Months } & \multicolumn{9}{|c|}{ Clearness Index } \\
\hline & $\begin{array}{l}\text { Kuala } \\
\text { Terengganu }\end{array}$ & Kuching & $\begin{array}{l}\text { Kota } \\
\text { Kinabalu }\end{array}$ & $\begin{array}{l}\text { Kota } \\
\text { Bharu }\end{array}$ & Senai & $\begin{array}{l}\text { Bayan } \\
\text { Lepas }\end{array}$ & $\begin{array}{l}\text { Kuala } \\
\text { Lumpur }\end{array}$ & $\begin{array}{l}\text { Petaling } \\
\text { Jaya }\end{array}$ & $\begin{array}{l}\text { Bandar } \\
\text { Baru Bangi }\end{array}$ \\
\hline January & 0.54 & 0.35 & 0.55 & 0.51 & 0.44 & 0.59 & 0.46 & 0.46 & 0.38 \\
\hline February & 0.62 & 0.38 & 0.57 & 0.52 & 0.57 & 0.57 & 0.48 & 0.49 & 0.44 \\
\hline March & 0.57 & 0.41 & 0.56 & 0.53 & 0.45 & 0.54 & 0.46 & 0.42 & 0.39 \\
\hline April & 0.64 & 0.36 & 0.59 & 0.54 & 0.47 & 0.52 & 0.46 & 0.46 & 0.43 \\
\hline May & 0.54 & 0.37 & 0.53 & 0.48 & 0.43 & 0.47 & 0.44 & 0.43 & 0.44 \\
\hline June & 0.48 & 0.48 & 0.53 & 0.48 & 0.47 & 0.49 & 0.46 & 0.46 & 0.45 \\
\hline July & 0.53 & 0.45 & 0.51 & 0.45 & 0.41 & 0.45 & 0.43 & 0.43 & 0.48 \\
\hline August & 0.53 & 0.41 & 0.51 & 0.46 & 0.41 & 0.44 & 0.42 & 0.43 & 0.40 \\
\hline September & 0.53 & 0.43 & 0.50 & 0.50 & 0.43 & 0.46 & 0.44 & 0.44 & 0.39 \\
\hline October & 0.44 & 0.41 & 0.53 & 0.47 & 0.42 & 0.45 & 0.43 & 0.44 & 0.39 \\
\hline November & 0.49 & 0.41 & 0.53 & 0.39 & 0.42 & 0.49 & 0.41 & 0.41 & 0.35 \\
\hline December & 0.42 & 0.36 & 0.54 & 0.37 & 0.45 & 0.53 & 0.42 & 0.42 & 0.37 \\
\hline Annual average & 0.53 & 0.40 & 0.54 & 0.47 & 0.45 & 0.50 & 0.44 & 0.44 & 0.41 \\
\hline
\end{tabular}



Fig. 8: Monthly average clearness index at the research site

index value is approximately 0.53 . It is observed that the major seasons (dry and rainy) are reflected in the solar climate of Terengganu. The clearness of the sky is generally higher during the dry season. During the northeast monsoon, when both the clearness index and temperature are low, global solar radiation is likely to be low. Due to the low clearness index the solar radiation energy reduces dramatically.

The monthly mean clearness indexes of other cities (Kuching, Kota Kinabalu, Kota Baru, Senai, Bayan Lepas, Kuala Lumpur, Petaling Jaya and Bandar Baru Bangi) of Malaysia (Kamaruzzaman and Othman, 1992) are compared with Kuala Terengganu monthly mean clearness index, as shown in Table 3. It is clear that the monthly average clearness index over the course of the year is higher for Kuala Terengganu, though in few months Kota Kinabalu and Bayan Leps cities have higher monthly mean clearness index values.

\section{CONCLUSION}

Generation of average solar radiation is very important for the calculations concerning many solar applications. In this study, an average reference year for daily global solar radiation for Terengganu, Malaysia is produced in a tabular form using mid term measured data. It is expected that these average solar radiation years will be useful to the designers of solar energy systems as well as those who need to have daily solar radiation data for Terengganu. Daily average solar radiation data show that the month of April had the highest monthly average daily irradiation of $6566 \mathrm{~W} \mathrm{~m}^{-2}$ day $^{-1}$ and the highest daily peak in solar irradiation of $7560 \mathrm{~W} \mathrm{~m}^{-2} \mathrm{day}^{-1}$. December had the lowest monthly average daily solar irradiation of $3715 \mathrm{~W} \mathrm{~m}^{-2}$ day $^{-1}$. The average yearly cumulative irradiation for Terengganu is $6905.8 \mathrm{MJ} \mathrm{m}^{-2}$ year $^{-1}$. In an average year, the dry period (February to May and September) contributes about $47.19 \%$ of the annual total. The worst month (December) contributes least, being responsible for only about $5.89 \%$.

The data show a range of monthly average wind speed variations of 2.1-4.7 m sec${ }^{-1}$. Monthly mean of the maximum wind speed were higher in the months of December to February. The highest daily maximum and monthly average temperatures were $\sim 35$ and $30^{\circ} \mathrm{C}$ in August and April, respectively. The minimum daily average temperature was recorded $22.8^{\circ} \mathrm{C}$ on February 22,2008 . The clearness index varies between 0.06 and 0.76 during one complete year. In northeast monsoon, the clearness indexes are very low, but other periods almost clear sky condition exists. The monthly average clearness index varies between 0.42 and 0.64 . The average clearness index value is approximately 0.53 . 


\section{ACKNOWLEDGEMENT}

The researchers would like to thank the Malaysian Meteorological Department for providing the data to this research. Also the authors would like to thanks Maritime Technology Department, University Malaysia Terengganu (UMT) and Engineering Science Department, UMT for providing technical and financial support.

\section{REFERENCES}

Abdul Karim, M.A.B. and A.M.B. Razali, 2002. Forecasting global solar radiation using statistical method. Sains Malaysian, 31: 149-158.

Argiriou, A., S. Lykoudis, S. Kontoyiannidis, C.A. Balaras and D. Asimakopoulos et al., 1999. Comparison of methodologies for TMY generation using 20 years data for Athens, Greece. Solar Energy, 66: 33-45. DOI: 10.1016/S0038-092x(99)00012-2

Azhari, A.W., K. Sopian, A. Zaharim and M.A. Ghoul, 2008. A new approach for predicting solar radiation in tropical environment using satellite images-case study of Malaysia. WSEAS Trans. Environ. $\quad$ Dev., $\quad$ 4: 373-378. http://pkukmweb.ukm.my/ upak/pdffile/drazami/3 0-870N.pdf

Chuah, D.G.S. and S.L. Lee, 1981. Solar radiation estimate in Malaysia. Solar Energy, 26: 33-40. DOI: $10.1016 / 0038-092 \times(81) 90109-2$

Chuah, D.G.S. and S.L. Lee, 1982. Solar radiation estimate in peninsular Malaysia-statistical representation. Energy Convers. Manage., 22: 71-84. DOI: 10.1016/0196-8904(82)90011-5

Duffie, J.A. and W.A. Beckman, 2006. Solar Engineering of Thermal Processes. 2nd Edn., John Wiley and Sons, New York, ISBN: 978-0-47169867-8.

El-Sebaii, A.A. and A.A. Trabea, 2003. Estimation of horizontal diffuse solar radiation in Egypt. Energy Convers. Manage., 44: 2471-2482. DOI: 10.1016/S0196-8904(03)00004-9

Fagbenle, R.L., 1995. Generation of a test reference year for Ibadan, Nigeria. Energy Convers. Manage., 36: 61-63. DOI: 10.1016/01968904(94)00039-3

Gazela, M. and E. Mathioulakis, 2001. A new method for typical weather data selection to evaluate longterm performance of solar energy systems. Solar Energy, 70: 339-348. DOI: 10.1016/S0038092X(00)00151-1
Hu, H.C. and J.T. Lim, 1983. Solar and net radiation in Peninsular Malaysia. Int. J. Climatol., 3: 271-283. DOI: 10.1002/joc.3370030306

Kamaruzzaman, S. and M.Y.H. Othman, 1992. Estimates of monthly average daily global solar radiation in Malaysia. Renew. Energy, 2: 319-325. DOI: 10.1016/0960-1481(92)90044-4

Li, D.H.W. and J.C. Lam, 2000. Solar heat gain factors and the implications for building designs in subtropical regions. Energy Build., 32: 47-55. DOI: 10.1016/S0378-7788(99)00035-3

Malaysian Meteorology Department, (MMD), 2004. Solar date. http://www.kjc.gov.my/home_e.html

Marion, W. and K. Urban, 1995. User's manual for TMY2s. National Renewable Energy Laboratory, Colorado, USA. http://rredc.nrel.gov/solar/pubs/tmy2/overview.html

Petrakis, M., H.D. Kambezidis, S. Lykoudis, A.D. Adamopoulos and P. Kassomenos et al., 1998. Generation of a typical meteorological year for Nicosia, Cyprus. Renew. Energy, 13: 381-388. DOI: 10.1016/S0960-1481(98)00014-7

Said, S.A.M. and H.M. Kadry, 1994. Generation of representative weather-year data for Saudi Arabia. Applied Energy, 48: 131-136. DOI: 10.1016/03062619(94)90019-1

Shaltout, M.A.M. and M.T.Y. Tadros, 1994. Typical solar radiation year for Egypt. Renew. Energy, 4: 387-393. DOI: 10.1016/0960-1481(94)90045-0

SOLAR4POWER, 2009. Global Solar Power Map \#7. East Asia, Macronesia and Pacific. http://www.solar4power.com/map7-global-solarpower.html

Wong, L.T. and W.K. Chow, 2001. Solar radiation model. Applied Energy, 69: 191-224. DOI: 10.1016/S0306-2619(01)00012-5

Zaharim, A., A.M. Razali, T.P. Gim and K. Sopian, 2009. Time series analysis of solar radiation data in the tropics. Eur. J. Sci. Res., 25: 672-678. http://www.eurojournals.com/ejsr_25_4_15.pdf 